\title{
Spatial variability of air temperature in a free-stall in the Northeastern semi-arid region of Brazil
}

\author{
Indira C. M. Gonçalves ${ }^{1}$, Silvia H. N. Turco ${ }^{1} \&$ Clóvis M. C. Ramos ${ }^{1}$ \\ ${ }^{1}$ Universidade Federal do Vale do São Francisco/Colegiado de Pós Graduação em Engenharia Agrícola. Juazeiro, BA. E-mail: indira_cristiane@hotmail.com \\ (Corresponding author); silvia.turco@univasf.edu.br; clovis.ramos@univasf.edu.br
}

\section{Key words:}

dairy cattle

thermal comfort geostatistics animal production systems precision animal production

\begin{abstract}
A B S T R A C T
The knowledge on the spatial variability of climatic attributes and the building of Kriging maps can assist in the design and management of confined animal facilities, by allowing a spatial visualization that is helpful for the planning and control of information from the production environment. The study aimed to characterize the spatial variability of air temperature in a free-stall barn used for dairy cattle confinement located in Petrolina-PE, Brazil, in different seasons and at different times. The variable air temperature was recorded at 136 points distributed in the areas under the shed and the shade cloth for the study of spatial variability and the construction of maps by Kriging. Air temperature data was collected in the winter and in the summer, in the months of July and August (2013) and January and February (2014), at different times ( 9 and $15 \mathrm{~h}$ ). According to the results, the use of geostatistics enabled to define areas with different spatial variabilities in air temperature and specific areas in the free-stall with values higher than the recommended levels for thermal comfort. In addition, the central part of the facility is the region with the lowest values of air temperatures, due to the presence of a ridge vent.
\end{abstract}

\section{Palavras-chave:}

bovinos leiteiros

conforto térmico

geoestatística

sistemas de produção animal

zootecnia de precisão

\section{Variabilidade espacial da temperatura do ar de um free-stall na região semiárida nordestina do Brasil}

\section{R E S U M O}

O conhecimento da variabilidade espacial de atributos climáticos e a construção de mapas de krigagem podem auxiliar no projeto e no manejo de instalações para animais confinados, ao permitir uma visão espacial útil ao planejamento e ao controle das informações do ambiente de produção. O trabalho teve, como objetivo principal, caracterizar a variabilidade espacial da temperatura do ar de um galpão free-stall utilizado para confinamento de bovinos leiteiros, localizado na cidade de Petrolina, PE, em diferentes estações e horários. A variável temperatura do ar foi registrada em 136 pontos distribuídos na área do galpão e sombrite, para o estudo da variabilidade espacial e a construção de mapas por krigagem. As coletas dos dados de temperatura do ar foram realizadas nas estações de inverno e verão, nos meses de julho e agosto (2013), janeiro e fevereiro (2014) em diferentes horários (9 e 15 h). Por meio dos resultados obtidos foi possível definir áreas com diferentes variabilidades espaciais para temperatura do ar e áreas específicas no free-stall que apresentaram valores acima do recomendado para o conforto térmico animal. Notou-se também que a parte central da instalação é a região que apresentou os menores valores de temperatura do ar devido à presença de um lanternim. 


\section{INTRODUCTION}

Livestock farming is an activity highly dependent on climatic factors, which can affect animal yield and management (Oliveira et al., 2013). The effect of climatic conditions on the development of dairy cows is expressive, especially in tropical and subtropical regions. Thus, the knowledge on the functional relationships between animals and the environment allows adopting procedures that increase the efficiency of dairy farming (Marcheto et al., 2002).

The optimal temperature for milk production depends on the species, breed and degree of tolerance to heat and cold. For Holstein-Friesian cows, great milk-producers, the thermal neutrality zone in lactation, in terms of air temperature, generally occurs in the interval between 4 and $26^{\circ} \mathrm{C}$, which impairs the raising of these animals under tropical climate conditions (Perissinotto \& Moura, 2007).

One way of minimizing the undesirable climatic conditions is the use of facilities, which must provide comfort for the animals, allowing them to express their production potential. Facilities must be built and planned with the main objective of reducing the action of stress agents, which can cause undesirable effects on the animals. Environmental variables are controlled with different building materials, dimensioning of the physical space, density and climatization systems (Almeida et al., 2010)

The management of the microclimate inside animal production facilities has been widely used in the search for the adjustment of thermal comfort conditions for the housed animals, due to the influence of meteorological elements that favor or hamper their development. This management encompasses the strategies used to reduce the negative effects of stress agents on the animal-environment relationship (Silva et al., 2012).

In order to better evaluate the animal production environment, innovative methods, computational evaluation tools and the help in decision-making have been used in the control of the welfare of the confined animals (Borges et al., 2010).

In this context, this study aimed to characterize the spatial variability of air temperature in a free-stall located in the Brazilian semiarid region, in the winter and summer, using geostatistical tools.

\section{Material ANd Methods}

The study was carried out on the Campus of Agricultural Sciences of the Federal University of the São Francisco Valley, where the data were collected in a free-stall of the area destined to rural constructions, in the municipality of Petrolina-PE, Brazil, $721 \mathrm{~km}$ distant from the state capital and located at the geographical coordinates of $9^{\circ} 09^{\prime} \mathrm{S} 40^{\circ} 22^{\prime}$ $\mathrm{W}$, with mean altitude of $365 \mathrm{~m}$ and mean annual rainfall of $450 \mathrm{~mm}$. According to the Köppen-Geiger classification, the climate in the city is BshW, semi-arid tropical, dry and hot.

The facility was built for the confinement of HolsteinFriesian cows, which remained in the area during the experiment. The confinement facility has a 1.20 -m-wide ridge vent, with North-South orientation. The shed is supported by pre-cast concrete pillars, covered with ceramic tiles, and has ceiling height of $2.60 \mathrm{~m}$, eaves of $1.50 \mathrm{~m}$ and open sides. The floor is made of grooved concrete in order to facilitate the drainage of wastewater.

Besides the covered area in the free-stall, the facility has a shaded area, with width of $7.8 \mathrm{~m}$ and length of $60.0 \mathrm{~m}$. Part of this area is covered with shade cloth, in order to reduce the incidence of solar radiation on the animals. The design scheme of the free-stall is shown in Figure 1.

The study was conducted in two seasons: Winter Treatment 1 (WIN) and Summer - Treatment 2 (SUM), when air temperature data were collected in the free-stall, in the months of July and August 2013 and January and February 2014, twice a day, at 9:00 $\mathrm{h}$ and at 15:00 h. According to the Laboratory of Meteorology of the UNIVASF, the mean values of relative air humidity in the city of Petrolina, at the time of the collections (9:00 and 15:00 h) were 54.7 and 30.2\% for the months of July and August 2013, and 60.4 and 39.3\% for January and February 2014, respectively.

Geostatistical analysis was performed for the air temperature in the areas of the free-stall under the shed and the shade cloth. The data were collected at 136 equidistant points inside the facility, spaced by $3 \mathrm{~m}$. The measurements were performed at a height of $1.5 \mathrm{~m}$ from the floor, in each position of the regular grid of points.

Air temperature data were recorded using a portable thermal anemometer (Instruterm - TAD 500), with temperature recording range from -15 to $50^{\circ} \mathrm{C}$, and subjected to geostatistical analysis. Data variability was evaluated using descriptive statistical analysis, through the parameters mean, median and coefficient of variation (CV).

The spatial dependence was verified through adjustments of semivariograms (Vieira, 2000), based on the assumption of intrinsic stationary process, which is estimated by:

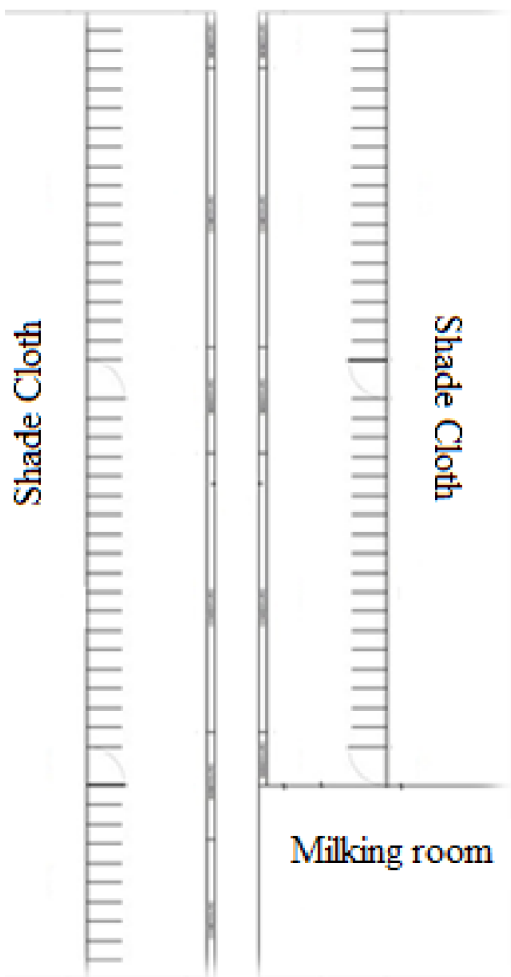

Figure 1. Design scheme of the free-stall 


$$
\gamma(h)=\frac{1}{2 N(h)} \sum_{i=1}^{N(h)}\left[Z\left(x_{i}\right)-Z\left(x_{i}+h\right)\right]^{2}
$$

where:

$\mathrm{N}(\mathrm{h})$ - number of experimental pairs of observations $\mathrm{Z}\left(\mathrm{x}_{\mathrm{i}}\right)$ and $\mathrm{Z}\left(\mathrm{x}_{\mathrm{i}}+\mathrm{h}\right)$ separated by a distance $\mathrm{h}$.

The semivariogram is represented by the graph $\mathrm{y}(\mathrm{h})$ versus h. From the adjustment of a mathematical model to the calculated $y(h)$ values, the coefficients of the theoretical model are calculated for the semivariogram (nugget effect, $\mathrm{C}_{0}$; sill, $\mathrm{C}_{0}+\mathrm{C}_{1}$; and the range, a). The selection of the best model was based on the residual sum of squares and on the coefficient of multiple determination $\left(\mathrm{R}^{2}\right)$.

According to Trangmar et al. (1985), the nugget effect is the value of the semivariance for the distance zero $(h=0)$ and represents the analytical error, i.e., it indicates the variability that cannot be explained; the range represents the distance between the origin and the sill. From this point on, it is considered that spatial dependence no longer occurs between the samples.

The degree of spatial dependence of the studied attributes was analyzed using the classification of Cambardella et al. (1994), in which the spatial dependence is considered strong for semivariograms with nugget effect $<25 \%$ of the sill, moderate when it is between 25 and $75 \%$ and weak when it is $>75 \%$.

The theoretical semivariogram models considered in the study were: spherical, exponential, linear and Gaussian, which were adjusted through the program GS + 7.0. Then, these models were used for the estimation of air temperature data in non-measured points, using the interpolation method known as ordinary Kriging. Then, the maps were formatted and edited using the program SURFER 8.0.

\section{Results AND Discussion}

The values of means, medians and coefficients of variation for air temperature data are shown in Table 1. These results correspond to the descriptive statistics performed in the collected data.
Based on the mean values obtained from the spatial distribution data, air temperature remained within the comfort range only in WIN at $9 \mathrm{~h}$; according to Perissinotto et al. (2007), these values must be between 4 and $26^{\circ} \mathrm{C}$ for Holstein-Friesian cows. For both treatments, at the other observation times, the parameter air temperature was higher than the maximum limit recommended for lactating cows.

Mean and median values are similar in both studied treatments, indicating that the data do not show expressive asymmetry. According to Little \& Hills (1978), when mean, median and mode values are similar, the data have or are close to normal distribution. This can be an indication that measurements of central tendency are not dominated by atypical values in the distribution (Cambardella et al., 1994). Similar results were reported by Faria et al. (2008), who obtained normality for the attribute air temperature in a climatized free-stall for milk cattle.

High values of the coefficient of variation (CV) can be considered the first indication of data heterogeneity. Considering the classification criteria of Warrick \& Nielsen (1980), which establishes low variability for CV $<12 \%$, medium variability for $12 \%<\mathrm{CV}<62 \%$ high variability for $\mathrm{CV}>62 \%$, the variable air temperature showed low variability $(\mathrm{CV}<12 \%)$ at the different times and in the different treatments. These results agree with those reported by Silva et al. (2012), who obtained low variability for temperature data in a non-climatized free-stall.

The parameters of the geostatistical analysis, such as the adjusted semivariogram model, nugget effect, sill, range and degree of spatial dependence, are shown in Table 2.

The results of the geostatistical analysis showed spatial dependence of air temperature in both treatments (Table 2 ). The analysis of the semivariograms for the climatic attributes did not indicate any preferential direction, i.e., as claimed by Vieira (2000), in this case, the data do not have anisotropy and the spatial variability occurs in the same way in all directions.

The studied variable fitted to the spherical semivariogram model, except for the treatment WIN, which fitted to the Gaussian model at $9 \mathrm{~h}$, and for the treatment SUM, which fitted to the exponential model at $15 \mathrm{~h}$.

According to Isaaks \& Srivastava (1989), these models are transitory, because they have sill, i.e., from a certain value

Table 1. Descriptive statistical analysis of air temperature $\left({ }^{\circ} \mathrm{C}\right)$ at 9 and $15 \mathrm{~h}$

\begin{tabular}{cccccccc}
\hline Variable & Treatment & Time & Maximum & Minimum & Mean & Median & CV(\%) \\
& WIN & $9 \mathrm{~h}$ & 27.9 & 23.3 & 25.2 & 25.6 & 3.76 \\
\multirow{2}{*}{ Tair $\left({ }^{\circ} \mathrm{C}\right)$} & & $15 \mathrm{~h}$ & 31.7 & 28.2 & 29.1 & 29.0 & 1.43 \\
& & $9 \mathrm{~h}$ & 32.4 & 28.1 & 29.7 & 30.6 & 3.04 \\
& SUM & $15 \mathrm{~h}$ & 36.6 & 34.1 & 34.5 & 34.8 & 1.29 \\
\hline
\end{tabular}

Tair - Mean air temperature; CV - Coefficient of variation; WIN - Winter; SUM - Summer

Table 2. Parameters of the experimental semivariograms of air temperature $\left({ }^{\circ} \mathrm{C}\right)$ at 9 and at $15 \mathrm{~h}$

\begin{tabular}{|c|c|c|c|c|c|c|c|c|}
\hline Variable & Treat. (2) & Time & Model & $\mathbf{C}_{0}{ }^{(3)}$ & $C_{0}+C_{1}^{(4)}$ & Range (m) & $\begin{array}{c}\text { DSD }^{(5)} \\
(\%)\end{array}$ & $\mathrm{R}^{2}$ \\
\hline \multirow{4}{*}{ Tair ${ }^{(1)}\left({ }^{\circ} \mathrm{C}\right)$} & \multirow{2}{*}{ WIN } & $9 \mathrm{~h}$ & Gaussian & 0.13 & 0.93 & 10.01 & 86.40 & 0.78 \\
\hline & & $15 \mathrm{~h}$ & Spherical & 0.09 & 0.32 & 92.42 & 72.90 & 0.64 \\
\hline & \multirow{2}{*}{ SUM } & $9 \mathrm{~h}$ & Spherical & 0.11 & 0.90 & 23.50 & 88.00 & 0.89 \\
\hline & & $15 \mathrm{~h}$ & Exponential & 0.05 & 0.28 & 18.75 & 83.50 & 0.78 \\
\hline
\end{tabular}

(1) Tair - Mean air temperature ( $\left.{ }^{\circ} \mathrm{C}\right)$; (2) Treat. - Treatment; ${ }^{(3)} \mathrm{C}_{0}-$ Nugget effect; (4) $\mathrm{C}_{0}+\mathrm{C}_{1}-\mathrm{Sill}$; (5) $\mathrm{DSD}$ - Degree of spatial dependence; $\mathrm{R}^{2}-$ Coefficient of determination obtained through the cross-validation method; WIN - Winter; SUM - Summer 
of distance between samples, spatial dependence no longer occurs. This distance is referred to as range.

According to Table 2, the highest range occurred in the treatment WIN at $15 \mathrm{~h}$, for which the fitted model managed to verify spatial dependence of air temperature beyond the facility limits, which was not observed at the other times.

The nugget effect reflects the non-explained variability as a function of the distance of the sampling used, such as local variations, analysis errors, sampling errors etc. Since it is impossible to quantify the individual contribution of these errors, the nugget effect can be expressed as percentage of the sill, thus facilitating the comparison of the degree of spatial dependence of the studied variables (Trangmar et al., 1985).

As to the degree of spatial dependence (DSD), it showed that there was weak spatial dependence for all the studied times in both treatments.

The Kriging maps of air temperature are shown in Figure 2. According to the maps, air temperature values at $9 \mathrm{~h}$ showed higher variability inside the facility than at 15 h. At $15 \mathrm{~h}$, the high homogeneity of air temperature data occurred because the facility has open sides and a ridge vent. In addition, at this time, the facility has been exposed to a longer period of solar radiation, compared with $9 \mathrm{~h}$,

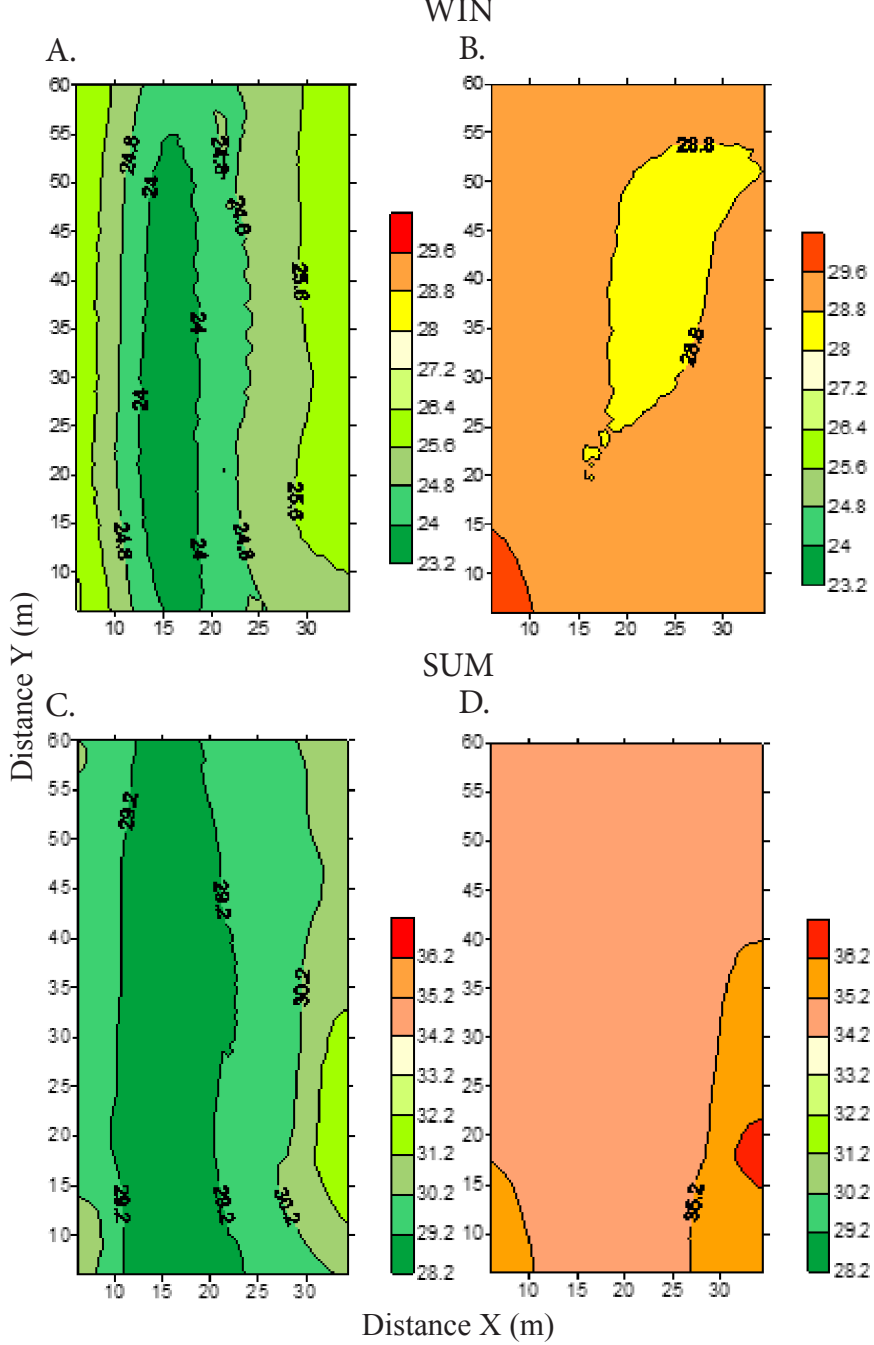

Figure 2. Kriging maps of mean air temperature $\left({ }^{\circ} \mathrm{C}\right)$ at 9 $h$ in the winter - WIN (A), $15 \mathrm{~h}$ in the WIN (B), $9 \mathrm{~h}$ in the summer - SUM (C) and $15 \mathrm{~h}$ in the SUM (D) which favors the heating of the air inside the free-stall and, through heat exchange mechanisms such as conduction, convection and radiation, it causes air temperature values to be more homogeneous.

Air temperatures were lower in the covered area of the free-stall, especially in its center. This can be explained by the presence of the ridge vent, an opening on the top of the roof, which is highly recommendable for proper ventilation, since it allows a continuous renewing of air, resulting in an adequate environment for the animals. The highest values were observed at the edges of the free-stall, in the solarium, indicating a possible heat stress for the animals when they are in this region, which can affect the yields of milking cows.

The lowest values of air temperature occurred at $9 \mathrm{~h}$, in both treatments; however, only in the winter (WIN), in virtually the entire facility, air temperature values were within the thermal comfort zone of Holstein-Friesian cows (between 4 and $26^{\circ} \mathrm{C}$ ). For the other times, both in winter and summer, air temperature values were above the thermal comfort zone for these animals.

Since the facility has no cooling system, it is advisable that during the winter, at $15 \mathrm{~h}$, and during the summer, at all times, the animals stay confined close to the beds, in the central part of the facility, since it provides lower temperatures for the animals and a consequent lower thermal stress.

Due to the higher solar radiation at $15 \mathrm{~h}$, air temperature data were higher in both seasons and the maps showed higher homogeneity of these values at this time. All temperatures in the free-stall, in the areas under the shed and the shade cloth, at 9 and $15 \mathrm{~h}$ in the summer and at $15 \mathrm{~h}$ in the winter, were above the recommended value for the thermal comfort of the animals. In other words, regardless of the location of the animals inside the facility, at this time they are susceptible to thermal stress, which can cause reduction in milk production. This is consistent with Silva et al. (2008), who observed losses in milk production of about $0.85,1.82,2.78$, $3.75,4.71$ and $5.70 \mathrm{~kg}$ of milk animal ${ }^{-1} \mathrm{~d}^{-1}$ for animals with Production Level (PL) of 10, 15, 20, 25, 30 and $35 \mathrm{~kg}$ animal $^{-1} \mathrm{~d}^{-1}$, during the hotter months of the year, in various regions of the state of Pernambuco. These authors also claim that in the semi-arid region of Pernambuco, the best climatic conditions for animals with PL of 20 and $25 \mathrm{~kg}$ animal ${ }^{-1} \mathrm{~d}^{-1}$ occur in the micro-regions of Garanhuns, Brejo and the Valleys of Ipojuca and Ipanema.

Due to the spatial variability of air temperature inside the facility, the animals will be susceptible to some areas hotter than others, at the same times, possibly causing irregularities in the production of milk by the confined cows. Thus, the chronical exposure to solar radiation and environments with high temperatures must be reduced, providing animals with additional opportunities to lose heat, such as systems of ventilation, sprinkler and evaporative cooling. Many of these strategies can be implemented at low direct costs and other alternatives can still be used based on cattle yield (Ferreira et al., 2006).

Barbosa et al. (2004) observed that providing shade to lactating Holstein-Friesian cows during the summer is an 
efficient way to improve their comfort, as well as the use of water spray on the animals. These authors also claim that, in the productive aspect, the use of water spray on the animals proved to be efficient and can be recommended under certain technical and economic criteria, since the results are not always positive.

Araújo et al. (2010) also found positive results regarding the increase in yield of Holstein-Friesian dairy cows, using misting and ventilation simultaneously. This management maintained the animals in a safe zone, out of the thermal stress all the time, providing conditions for maximum milk yield.

Thus, it is evident the need for the installation of cooling mechanisms in the free-stall located in Petrolina, in the semiarid region of Pernambuco, especially on the sides of the facility, in order to provide optimal and homogeneous conditions of air temperature for the cows, collaborating to avoid thermal stress and, consequently, increasing animal yield.

\section{Conclusions}

1. There was spatial variability for the variable air temperature, and specific areas were identified in the freestall, where temperatures were above the recommended level for the thermal comfort of the animals.

2 . In the morning, for the Treatment 1 , winter, almost the entire facility has temperatures within the zone of thermal neutrality of the animals, and the lowest temperatures are mainly concentrated in its center, due to the presence of a ridge vent.

3. At $15 \mathrm{~h}$ in the winter and at 9 and $15 \mathrm{~h}$ in the summer, the entire facility has temperatures above the thermal comfort zone of the animals and can cause heat stress.

\section{Literature Cited}

Almeida, G. L. P.; Pandorfi, H.; Guiselini, C.; Almeida, G. A. P.; Morril, W. B. B. Investimento em climatização na pré-ordenha de vacas girolando e seus efeitos na produção de leite. Revista Brasileira de Engenharia Agrícola, v.14, p.1337-1344, 2010.

Araújo, H. B.; Tinôco, I. F. F.; Baêta, F. C.; Santos, J. H. T.; Souza, C. F. Avaliação de sistemas de resfriamento do ar para vacas com alta produtividade, em free-stalls. Engenharia na Agricultura, v.18, p.77-83, 2010. http://dx.doi.org/10.13083/1414-3984.v18n01a08

Barbosa, O. R; Boza, P. R.; Santos, G. T.; Sakagushi, E. S.; Ribas, N. P. Efeitos da sombra e da aspersão de água na produção de leite de vacas da raça Holandesa durante o verão. Acta Scientiarum. Animal Sciences, v.26, p.115-122, 2004.

Borges, G.; Miranda, K. O. S.; Rodrigues, V. C.; Risi, N. Uso da geoestatística para avaliar a captação automática dos níveis de pressão sonora em instalações de creche para suínos. Engenharia Agrícola, v.30, p.377-385, 2010. http://dx.doi.org/10.1590/s010069162010000300002

Cambardella, C. A; Moorman, T. B.; Novak, I. M.; Parkin, T. B.; Karlen, D. L.; Turco, R. F.; Konopka, A. E. Field scale variability of soil properties in Central Iowa soils. Soil Science Society America Journal, v.58, p.1501-1511, 1994. http://dx.doi. org/10.2136/sssaj1994.03615995005800050033x
Faria, F. F.; Moura, D. J.; Souza, Z. M.; Matarazzo, S. V. Variabilidade espacial do microclima de um galpão utilizado para confinamento de bovinos de leite. Ciência Rural, v.38, p.2498-2505, 2008. http://dx.doi.org/10.1590/S0103-84782008000900013

Ferreira, F.; Pires, M. F. A.; Martinez, M. L.; Coelho, S. G.; Carvalho, A. U.; Ferreira, P. M.; Facury Filho, E. J.; Campos, W. E. Parâmetros fisiológicos de bovinos cruzados submetidos ao estresse calórico. Arquivo Brasileiro de Medicina Veterinária e Zootecnia, v.58, p.732-738, 2006. http://dx.doi.org/10.1590/ S0102-09352006000500005

Isaaks, E. H.; Srivastava, R. M. An introduction to applied geoestatistics. New York: Oxford University, 1989. 561p.

Little, T. M.; Hills, F. J. Agricultural experimentation. New York: John Wiley \& Sons, 1978. 350p.

Marcheto, F. G.; Nääs, I. A., Salgado, D. Efeito das temperaturas de bulbo seco e de globo negro e do índice de temperatura e umidade, em vacas em produção alojadas em sistema de freestall. Brazilian Journal of Veterinary Research and Animal Science, v.39, p.320-323, 2002. http://dx.doi.org/10.1590/S141395962002000600008

Oliveira, E. C.; Delgado, R.C.; Rosa, S. R.; Souza, P. J. O. P.; Neves, L. O. Efeitos do estresse térmico sobre a produção de bovinos de leite no município de Marilândia - ES. Enciclopédia Biosfera, v.9, p.913-921, 2013.

Perissinotto, M.; Moura, D. J. Determinação do conforto térmico de vacas leiteiras utilizando a mineração de dados. Revista Brasileira de Engenharia de Biossistemas, v.1, p.117-126, 2007. http://dx.doi.org/10.18011/bioeng2007v1n2p117-126

Perissinotto, M.; Moura, D. J.; Cruz, V. F. Avaliação da produção de leite em bovinos utilizando diferentes sistemas de climatização. Revista Ciência Agrárias, v.30, p.135-142, 2007.

Silva, I. M.; Pandorfi, H.; Almeida, G. L. P.; Guiselini, C.; Caldas, A. M.; Jacob, A. L. Análise espacial das condições térmicas do ambiente pré-ordenha de bovinos leiteiros sob regimes de climatização. Revista Brasileira de Engenharia Agrícola e Ambiental, v.16, p.903-909, 2012. http://dx.doi.org/10.1590/ S1415-43662012000800013

Silva, T. G. F.; Turco, S. H. N; Zolnier, S.; Moura, M. S. B.; Sá, I. I. S. Variação regional do declínio na produção de leite durante o verão no estado de Pernambuco. Engenharia na Agricultura, v.16, p.109-123, 2008.

Trangmar, B. B.; Yost, R. S.; Wade, M. K.; Uehara, G. Applications of geostatistics to spatial studies of soil properties. Advances in Agronomy, v.38, p.45-94, 1985. http://dx.doi.org/10.1016/ S0065-2113(08)60673-2

Vieira, S. R. Geoestatística em estudos de variabilidade espacial do solo. In: Novais, R. F. Alvarez V., V. H.; Schaefer, C. E. G. R. (ed.). Tópicos em ciência do solo. Viçosa: Sociedade Brasileira de Ciência do Solo, v.1, p.1-53, 2000.

Warrick, A.W.; Nielsen, D. R. Spatial variability of soil physical properties in the field. In: Hillel, D. (ed.). Applications of soil physics. New York: Academic Press, 1980. p.319-344. http:// dx.doi.org/10.1016/b978-0-12-348580-9.50018-3 